\title{
Raw Materials for Processing of Sour-Sweet Slices of Red Beetroot
}

\author{
Karl Kaack \\ Aarhus University, Kirstinebjergvej 10, 5792 Aarslev, Denmark Institute for Agri Technology and \\ Food Innovation, Denmark
}

\begin{abstract}
Summary: This research focuses on the possibilities for fitting raw material quality characteristics of red beetroot for industrial processing of preserved sour sweet red beetroot slices size 40-50 and 50-60 mm. The relationship between degree days and beet root was significantly associated with the yield of beetroot that may be 90 and $100 \mathrm{th} \mathrm{h}^{-1}$ with a high percentage of roots with a diameter from 40 to $60 \mathrm{~mm}$. Optimization of beetroot length and size may increase the yield of slices during processing in order to improve the coordination between the growing of beets in the fields and the processing chain.

The quality characteristics color, sucrose, nitrate, oxalic acid, and mineral contents varied significantly between cultivars and the data from this research shows how to select new genetic variants that determine the most important properties of interest for the consumers. An increased level of nitrogen fertilization may decrease the purple colorant, keep the yellow colorants constant, decrease dry matter and soluble solids and increase nitrate, glutamic acid, and glutamine. Increases in harvest time may keep red colorants stable, increase yellow colorants, soluble solids sucrose, oxalic acid and water insoluble dry matter. The white precipitate in jars with beet slices may contain from 4 to $90 \%$ calcium oxalate and the amounts of this deposit depended on salt and sugar concentration and decreased by increasing $\mathrm{pH}$.
\end{abstract}

Keywords: Sowing - harvest - storage - color - texture - oxalic acid - white sediment.

\section{INTRODUCTION}

In the north western part of Europe are preserved sour sweet slices of beetroots produced in brines with sugar, vinegar and some spices may be used as a decoration and flavor ingredient upon several kinds of open rye or white wheat bread. They are often served withhot dishes together with different kinds of meats, boiled potatoes and the most important basic sensory tests carried out using hedonic scales have shown that sweetness, sourness and texture are very important quality characteristics [1] that are primarily are combined with a high level of red and yellow colorants [2]. Beetroot slices are produced industrially in two sizes with diameter $40-50$ or $50-60 \mathrm{~mm}$ that are packed in glass jars and pasteurized in brine made from sugar, vinegarand eventually some characteristic vegetable spices in water [2]. Considerations in 1973 regarding application of ball shaped or cylindrical beetroots resulted in determination of size distribution of three ball shaped cultivars 'Grosby', 'Detroit'and 'Rubia' resulted in 50,57 and $60 \%$ in size 40-60 mm, while the cylindrical cultivars 'Cylinder', 'Formanova' and 'Rød Valse' yielded 74, 87 and $96 \%$ slices with diameter 50 to $60 \mathrm{~mm}$ showing that processing of cylindrical beets was the most fruitful. Danish producers of beet slices in 1970 found high percentages completelywhite and partially white beets in the raw materials of 'Formanova' and that forced them to use synthetically colorants. The concentration of betanine in these beets varied significantly from $200 \mathrm{mg} 100 \mathrm{~g}^{-1}$ in small beets to less than $100 \mathrm{mg} 100 \mathrm{~g}^{-1}$ in 'Formanova' beets weighing $250 \mathrm{~g}$. These data resulted in a breeding program with successively selection of 'Formanova' in three generations. The average concentration of betanin, sucrose in the finally selected beets was $79.1 \mathrm{mg}$ betanin $100 \mathrm{~g}^{-1}$ and $13.2 \mathrm{~g}$ sucrose in $100 \mathrm{~g}^{-1}$ beet. The purple colorof beet slices is due to presence of redviolet betalain and yellow-orange betaxanthin pigments [3] and the sour-sweet flavor of the processed beet slices are due to a combination of the sour flavorfrom vinegar with the sweet flavor of sucrose [1, $2,3,4]$. The yellow and violet to red colorants in beets may be destroyed or eluted during cooking of beets in water. A common praxis among red beet growers with application of a high rate of nitrogen fertilizer to beets may influence the yield of beets and their contents of several chemical compounds in beets. Another reason to study the effects of nitrogen is that use of a high level of nitrogen may re- 
sult in a strong off-flavor of the sliced beets [5, 6]. Previous research in this areahas included the importance of cultivars, soil fertility, water status, sowing and harvest time, growth temperature, fertilization and their effects on sugars, nitrogen, alcohol soluble solids and colorants [7, 8]. However, data from coherent research including the crucial stages in the processing of high quality sour-sweet slices of beetroot was not carried out taking growing, harvesting, cool storage and industrially processing methods into consideration. It was expected that research in beet growth rate may depend significantly on cultivar and temperature determined as degree days.

Therefore, the aim of this study was to study the effects of fertilization, sowing, growing and storage ofraw beetroot characteristics in order to optimize the industrial processing of beetroot slices.

\section{MATERIALS AND METHODS}

\section{Field experiments}

Field experimentswere carried out on sandy soil at the experimental field at Aarhus University according to common horticultural praxis regarding nitrogen fertilization, sowing, weed control, harvest time and cool storage.Experiment one included studies of the effects of four sowing and four harvest dates on growth rate, size distribution of the cylindrical cultivar 'Forono'in experiment oneand comparison of the growth rates of 'Forono', 'Halanga', 'Rød Valse' and 'Unik' in experiment two with one sowing and four harvesting dates[9, 10]. The third field experiment included growing of three cylindrical cultivars 'Cylinder', 'Formanova', 'Rød Valse' and three ball shaped cultivars 'Crosby', 'Detroit' and 'Rubia' that was used for comparison of the average and variation in slice diameter from cylindrical and ball shaped cultivars, respectively.Field experiment four encompassed growing of the four cylindrical cultivars 'Forono', 'Rød Valse', 'Unik' and 'Halanga' in order to determine the yield and quality characteristics by sowing $12^{\text {th }}$ Juneand determination of beetroot diameter of 40 beets in two replicates seven times during the growth period encompassing 6, 17, 31 August and 7, 14, 24, and 28 September using a caliper gauge. All beetroots from each cultivar were sorted in nine size classes with diameter from 3.5 to $8.0 \mathrm{~cm}$ and step length $0.5 \mathrm{~cm}$ using a mechanical sorting machine. Forty roots from each of the nine diameter classes of each cultivar were selected randomly and sliced using thickness $0.5 \mathrm{~cm}$.

All beetroots from each cultivar were sorted in nine size classes with diameter from 3.5 to $8.0 \mathrm{~cm}$ and step length $0.5 \mathrm{~cm}$ using a mechanical sorting machine. Forty roots from each of the nine diameter classes of each cultivar were selected randomly and sliced using thickness $0.5 \mathrm{~cm}$. Beet diameter was measured using a diaper. -Beetroots from 'Rød Valse'were also applied for determination of horizontal and vertical concentration of betacyaninsin five beetroot samples taken downwards from the lowest leaf scar to root tip using an eight $\mathrm{mm}$ cylindrical cork. Each of them was cut into pieces representing the horizontal and vertical contents of betacyaninin three replicates $(n=5)$. Beet diameter was measured using a diaper.

Experiment three included growing of the cultivar 'Forono', with harvest 5 September, 3 October and 31 October, encompassing three sorting sizes that were processed immediately after harvest. Another series of beetroot samplings were harvested 5 September, 19 September, 3 October, 17 October, 31 October and divided into seven samplingsin three replicates for cool storage at $3^{\circ} \mathrm{C}$. These samples were also used for determination of the mechanical damage during peeling and cooking andthe effects of various cooking and cooling temperatures.

Experiment four encompassed an experiment using circular pots in size $1 \mathrm{~m}^{2}$ with sandy soil and application of $0,32,65,129$ and $258 \mathrm{~kg} \mathrm{~N} \mathrm{ha}^{-1}$ in four rows of replicates $(\mathrm{n}=4)$.

Degree days in ${ }^{\circ} \mathrm{C}$ were determined using the sum of the average daily minimum $\left(\mathrm{T}_{\min }\right)$ and maximum temperature in $\left(\mathrm{T}_{\max }\right)$ and basis temperature $4.5^{\circ} \mathrm{C}$ (degree days $=\Sigma\left(\mathrm{T}_{\min }+\mathrm{T}_{\max }\right) / 2-(4.5)$ using data from the meteorological measurements at the experimental field institute in cooperation with Danish Meteorological Institute(DMI).

\section{Harvest}

The harvest of beetroots included manual removal of the beetroot leaves using a sharp kitchen knife and the major amount of soil was removed gently before the beetroots were transported to the processing facilities for washing by hand in tap water $\left(13^{\circ} \mathrm{C}\right)$, weighing and mechanical sorting by diameter into roots with diameter $<40,40-60$ and $>60 \mathrm{~mm}$ to determine their size distribution and 
yield $(\mathrm{n}=3)$. Thereafter the beetroots from each treatment were mixed carefully and packed into four or ten $\mathrm{kg}$ net bags made of plastic and kept in cool storage at $1^{\circ} \mathrm{C}$ and $98 \%$ relative humidity $(\mathrm{RH})$ until analysis and processing $(\mathrm{n}=3)$. Samples for analysis included raw materials that were frozen and stored at $-25^{\circ} \mathrm{C}$.

\section{Dry matter}

Dry matter was determined by vacuum drying at $20 \mathrm{~mm} \mathrm{Hg}$ for 20 hours at room temperature $\left(20^{\circ} \mathrm{C}\right)$ if the dry material was used for further analytical measurements of organic compounds or in a heating cabinet at $80^{\circ} \mathrm{C}$ for 20 hours by determination of minerals and dry matter only $(n=3)$. Water insoluble dry matter (Widm) was determined from $50 \mathrm{~g}$ macerated material weighed onto dried filters (S\&S 520S, $185 \mathrm{~mm}$ ), washing with boiling distilled water (Elgastat SB, BioSurplus, San Diego, USA) until complete removal of betanin and drying of the filters at $80^{\circ} \mathrm{C}$ for 20 hours $(n=3)$.

\section{Betacyanin and betaxanthin}

Betanin and betaxanthin were extracted from the macerated red beet materials using $0.05 \mathrm{M}$ phosphate buffer pH 6.5 (Merck, Darmstadt, Germany) and measurement of absorbance at 476, 538 and $600 \mathrm{~nm}$ in filtrated samples $(\mathrm{n}=3)$ using a spectrophotometer (Shimadzu, MPS 2000, Kyoto, Japan) and the extinction coefficient 60.700 for betanin and 25.373 for betaxanthin by calculation of betanin and betaxanthin according to [11].

Samples for measurement of the betaxanthin contents in both vertical and horizontal direction of 'Rød Valse' beetroots was taken from the lowest leaf scar to the root tip using a cylindrical cork drill $6.8 \mathrm{~mm}$ in diameter $(\mathrm{n}=4)$.

\section{White precipitate}

The amount of white precipitate in the bottom of the jars with preserved beetroot slices were isolated using centrifugation at 15,000 g (Sorwall Products, RC-SB, UK) and freeze drying (Martin Christ $\mathrm{GmbH}$, Gamma 1-20, Osterode am Harz, Germany) at $10^{-6} \mathrm{~mm} \mathrm{Hg}$ and -25 to $25^{\circ} \mathrm{C}$ ).

\section{Sugars}

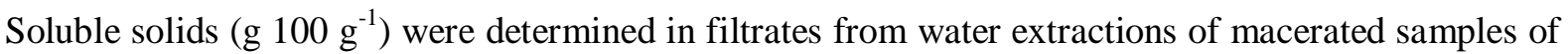
red beet material using a refractometer in three replicates (Bellingham + Stanley, RF M 800, Turnbridge Wells, Kent, UK). This method and gas liquid chromatography was used in the experiments with four red beetroot cultivars and cool storage of beetroots $(n=3)$.

Measurement of sucrose and glucose using gas liquid chromatography was initiated by treatment of $100 \mathrm{~g}$ red beet cubes using $300 \mathrm{~g}$ double distilled water and transfer of $5 \mathrm{~g}$ macerate that was diluted ten times with double distilled water. Then $1000 \mu \mathrm{L}$ extract were mixed with $100 \mu \mathrm{L}$ solution of trehalose in water $(2.50 \mathrm{~g}$ in $100 \mathrm{~mL})$ and diluted to $5 \mathrm{~mL}$ extracts with internal standard that were frozen to $-25^{\circ} \mathrm{C}$ and dried in vacuum $(25 \mathrm{~mm} \mathrm{Hg})$ before addition of $500 \mu \mathrm{L}$ pyridine and $500 \mu \mathrm{L}$ Trisil to silylate the sugars. Separation and quantification of sugars were obtained using a Hewlett Packard 5840 A gas chromatograph equipped with a $2.5 \mathrm{~m}$ column (i.d. 1/8 inch) packed with 80/100 mesh OV-1, an HP7651 automatic sampler, FID detector at $300^{\circ} \mathrm{C}$, air flow $300 \mathrm{~mL} \mathrm{~min}^{-1}$, hydrogen flow $30 \mathrm{~mL} \mathrm{~min}{ }^{-1}$, oven temperature $200-295^{\circ} \mathrm{C}$ increasing $4^{\circ} \mathrm{C} \mathrm{min}^{-1}$, attenuation $2^{8}$, slope 2 , area rejection $10^{4}$, and $10 \mathrm{ml} \mathrm{min}^{-1}$ nitrogen as carrier gas.

\section{Organic acids}

The gas chromatographic measurement of oxalic acid in three replicates was carried out using Pye Unicam 64 gas chromatograph combined with an integrator (Hewlett Packard 3370, Hillerød, Denmark) equipped with a stainless steel column $(5 \mathrm{~m}, 1 / 8$ inch i.d.) packed with $80 / 100$ mesh diatomite $\mathrm{CT}, 10$ p.c. CW $20 \mathrm{M}$. Injection temperature $200^{\circ} \mathrm{C}$, column temperature $50{ }^{\circ} \mathrm{C} 5 \mathrm{~min}, 6^{\circ} \mathrm{C} \min ^{-1}$ to $150^{\circ} \mathrm{C}$, carrier gas flow $40 \mathrm{~mL} \mathrm{~N}_{2} \mathrm{~min}^{-1}$, FID detector at $350^{\circ} \mathrm{C}$, air flow $300 \mathrm{~mL} \mathrm{~min}{ }^{-1}$, hydrogen flow $30 \mathrm{~mL}^{-1}$, slope $0.1 \mathrm{mV} \mathrm{min}^{-1}$ and injection of $10 \mu \mathrm{L}$ ester preparation. The standard curve was prepared using a solution of oxalic acid (10-50 $\left.\mathrm{mg} \mathrm{mL}^{-1}\right)$ in methanol $(\mathrm{n}=3)$.

\section{Amino acids}

Glutamin and glutamic acid determined using a Boehringer Manheim electrode system (Vienna, Austria). Nitrate was determined using a spectrophotometric method according to [11] Nilsson and using an ion selective electrode (Boehringer Manheim, Vienna, Austria), respectively. The number of repli- 
cates for these methods was three. Calcium, magnesium and potassium were measured using atom absorption spectrometry as described previously.

Flavor

Eight panel members aged 20-40 evaluated the flavor of sour sweet preserved beetroot slices at five sessions using a scale from 1 to 10 , was 1 was no off flavor and 10 was very intensive off flavor.

\section{Statistical analyses}

The statistical methods included linear and logarithmic regression, ranking, one-way and multiple ANOVA using a Statgraphic Statistical Package (Statistical Graphics, Version 4, Rockville, USA. Averages were separated using letters $\mathrm{P}<0.05$. Factor analysis included varimax rotation of normalized data and a Scree test was carried out according to $[12,13]$.

\section{RESULTS}

\section{Beetroot dimensions}

Percentage beetroots with diameter from 40 to $60 \mathrm{~mm}$ from the cylindrical cultivars 'Cylinder', 'Formanova' and 'Rød Valse' were 73, 87 and $96 \mathrm{w} / \mathrm{w} \%$ and significantly higher than 62, 57 and 60 w/w\% from ball formed cultivars 'Crosby', 'Detroit' and Rubia' in experiment $1(\mathrm{P}<0.05)$. The beetroot weights of these six cultivars were strongly related to their volume where weight $=\mathrm{k}_{1}+$ $\mathrm{k}_{2}{ }^{*}$ volume were $\mathrm{k} 1$ is the constant and $\mathrm{k} 2$ is regression coefficient for each cultivar $(\mathrm{P}<0.05)$. On this background it was concluded that using cylindrical beetroots is more efficient compared to use of ball formed beetroots (Table 1). This experiment included sowingof from May $1^{\text {st }}$ to $11^{\text {th }}$ July and harvestingfrom $14^{\text {th }}$ Aug to $7^{\text {th }}$ Nov in experiment 1 and to $1^{\text {st }}$ to July to harvest in August to October increased significantly linearly with degree days until the last harvesting in November. The constants in the regression equations were significantly different except for the first and latest harvest date for 'Forono' with the highest growth rates after the earliest and latest sowing and harvest dates. The slope of the regression equations belong to a relative similarity with growth rates from 0.02 to $0.04 \mathrm{~mm}$ degree day ${ }^{-1}$. The growth rate of the two pairs of cultivars including 'Halanga' and 'Unik' and 'Forono' and 'Rød Valse' was significantly different and that resulted in a significantly larger diameter on the first harvest dates for the first pair in comparison to the second pair. Because of the levels of significance of the obtained equations it was concluded that application of base temperature $4.5^{\circ} \mathrm{C}$ seems to be an optimum. 'Halanga' and 'Unik'obtained maximum diameter by harvest in the first week of August and 'Forono' had maximum one month later and the average diameter of 'Rød Valse' varied significantly over time. The percentage roots with diameter above $60 \mathrm{~mm}$ were significantly lowest for 'Forono' and the other three cultivars had similar percentage above $60 \mathrm{~mm}$ by harvest 31August. Maximum diameter was obtained in the first two weeks of September (Table 2), The significantly largest and lowest amount of beetroots with diameter above $60 \mathrm{~mm}$ were obtained for 'Unik' and 'Forono'. On the basis of these data it was concluded that the cultivar 'Forono' was the optimum cultivar for producing beetroot slices with diameter 40-60 mm. Growing ofthe cultivars 'Halanga' and 'Unik' may result in possibilities for earlier harvest. That could be an optimum choice by a low processing capacity in comparison to the use of one cultivar only. On this background it was concluded that the harvest and processing order must be 'Unik' before 'Halanga' before 'Forono', while 'Rød Valse' had the latest and least exact development in root diameter.

Table 1. Sowing, harvest and beet growth

\begin{tabular}{|c|c|c|c|c|c|c|}
\hline Cultivar & Sowing & Harvest & $\begin{array}{l}\text { Constant } \\
\mathrm{mm}\end{array}$ & $\mathrm{P}$ & $\begin{array}{l}\text { Slope } \\
\mathrm{mm}\left(\text { degree day }{ }^{\circ} \mathrm{C}^{-1}\right)\end{array}$ & $\mathrm{P}$ \\
\hline 'Forono' & $1^{\text {st }}$ May & $14^{\text {th }}$ Aug & 7.51 & $\mathrm{~ns}$ & 0.03952 & $* * *$ \\
\hline " & $20^{\text {th }}$ May & $17^{\text {th }}$ Sep & 10.58 & $* *$ & 0.02752 & $* * *$ \\
\hline$"$ & $17^{\text {th }}$ Jun & $31^{\mathrm{st}}$ Oct & 13.47 & $* * *$ & 0.02220 & $* *$ \\
\hline$"$ & $11^{\text {th }} \mathrm{Jul}$ & $7^{\text {th }}$ Nov & 0.50 & $\mathrm{~ns}$ & 0.04186 & $* *$ \\
\hline $\begin{array}{l}\text { 'Halanga' and } \\
\text { 'Unik' }\end{array}$ & $12^{\text {th }}$ Jun & $\begin{array}{l}10^{\text {th }} \text { and } 17^{\text {th }} \\
\text { Sep }\end{array}$ & 17.91 & $* *$ & 0.03264 & $* * *$ \\
\hline $\begin{array}{l}\text { 'Forono' and 'Red } \\
\text { Valse' }\end{array}$ & $"$ & $1^{\mathrm{st}} \mathrm{Oct}$ & 14.67 & $* *$ & 0.03115 & $* * *$ \\
\hline $\begin{array}{l}{ }^{\mathrm{T}} \text { Degeee days }=\Sigma(\mathrm{T} \\
(4.5) .\end{array}$ & $\left.+\mathrm{T}_{\max }\right) /$ & & & & & \\
\hline
\end{tabular}




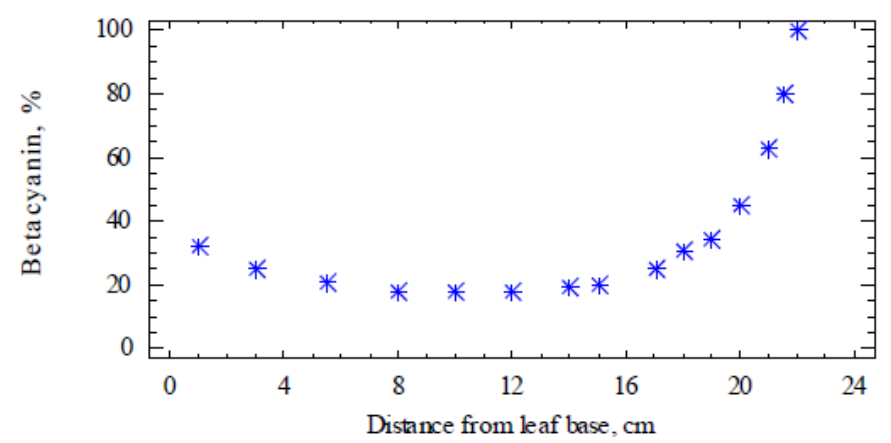

Fig 1. Vertical content of betacyanin in a beetroot (Rød Valse).

Table 2. Percentage beetroots with diameter 40-60 and > $60 \mathrm{~mm}$ at up to seven dates during the growth period.

\begin{tabular}{|l|l|l|l|l|l|l|l|l|}
\hline Harvest & 'Forono' & 'Halanga' & 'Rød Valse' & 'Unik' & 'Forono' & 'Halanga' & 'Rød Valse' & 'Unik' \\
\hline $6^{\text {th }}$ Aug & $53 \mathrm{c}$ & $70 \mathrm{a}$ & $45 \mathrm{c}$ & $73 \mathrm{a}$ & $3 \mathrm{~d}$ & $5 \mathrm{c}$ & & \\
\hline $17^{\text {th }} \mathrm{Aug}$ & $55 \mathrm{~b}$ & $73 \mathrm{a}$ & $60 \mathrm{~b}$ & $80 \mathrm{a}$ & $5 \mathrm{c}$ & $10 \mathrm{c}$ & & \\
\hline $31^{\text {st }} \mathrm{Aug}$ & $65 \mathrm{~b}$ & $73 \mathrm{a}$ & $70 \mathrm{a}$ & $73 \mathrm{a}$ & $10 \mathrm{~d}$ & $23 \mathrm{c}$ & $9 \mathrm{~d}$ & $20 \mathrm{c}$ \\
\hline $7^{\text {th }} \mathrm{Sep}$ & $73 \mathrm{a}$ & $73 \mathrm{a}$ & $63 \mathrm{~b}$ & $58 \mathrm{c}$ & $15 \mathrm{f}$ & $25 \mathrm{c}$ & $23 \mathrm{c}$ & $35 \mathrm{~d}$ \\
\hline $14^{\text {th }} \mathrm{Sep}$ & $73 \mathrm{a}$ & & $70 \mathrm{a}$ & $52 \mathrm{c}$ & $18 \mathrm{e}$ & $23 \mathrm{~d}$ & $23 \mathrm{~d}$ & $48 \mathrm{c}$ \\
\hline $24^{\text {th }} \mathrm{Sep}$ & $73 \mathrm{a}$ & & $68 \mathrm{~b}$ & $18 \mathrm{~d}$ & 18 & $25 \mathrm{c}$ & $25 \mathrm{c}$ & \\
\hline $28^{\text {th }}$ Sep & $73 \mathrm{a}$ & & $73 \mathrm{a}$ & & & & & \\
\hline
\end{tabular}

Late sowing and harvest resulted in significant decreases in beetroot length, diameter and weight of 'Forono' (Table 3).Roots from 'Forono' and 'Rød Valse' were significantly longer than roots from 'Halanga' and 'Unik'. The diameter of roots from 'Forono' in this experiment occurred in two significantly size classes with small significant differences, while the diameter of the four cultivars in experiment two were non-significantly different. The weight of beetroots within the two cultivar groups 'Forono' and 'Rød Valse' and'Halanga' and 'Unik', were non-significantly different, whereasthe difference in weight between the two groups were significant. A decrease in beetroot length is serious because shorter roots result in fewer slices by each root.

Table 3. Length, diameter and weight of analyzed and processed beetroots.

\begin{tabular}{|l|l|l|l|l|l|l|l|}
\hline Experiment & Cultivar & Sowing & Harvest & Length, cm & Diameter, cm & Weight, g & Roots, no \\
\hline One & 'Forono' & $1^{\text {st }}$ May & $14^{\text {th }}$ Aug & $15.3 \mathrm{a}$ & $42.6 \mathrm{a}$ & $223 \mathrm{a}$ & 240 \\
\hline$"$ & $"$ & $20^{\text {th }}$ May & $17^{\text {th }}$ Sep & $13.3 \mathrm{~b}$ & $42.8 \mathrm{a}$ & $189 \mathrm{~b}$ & $"$ \\
\hline$"$ & $"$ & $17^{\text {th }}$ Jun & $31^{\text {st }}$ Oct & $12.2 \mathrm{c}$ & $41.0 \mathrm{~b}$ & $163 \mathrm{c}$ & $"$ \\
\hline$"$ & $"$ & $1^{\text {st }}$ Jul & $"$ & $12.0 \mathrm{c}$ & $42.2 \mathrm{~b}$ & $155 \mathrm{~d}$ & $"$ \\
\hline Two & 'Forono' & $12^{\text {th }}$ Jun & $1^{\text {st }}$ Oct & $15.6 \mathrm{a}$ & $49.0 \mathrm{a}$ & $261 \mathrm{a}$ & 50 \\
\hline$"$ & 'Halanga' & $"$ & $10^{\text {th }}$ Sep & $11.8 \mathrm{~b}$ & 4 & $175 \mathrm{~b}$ & $"$ \\
\hline$"$ & 'Rød Valse' & $"$ & $1^{\text {st }}$ Oct & $15.7 \mathrm{a}$ & " & $251 \mathrm{a}$ & $"$ \\
\hline$"$ & 'Unik' & $"$ & $17^{\text {th }}$ Sep & $11.7 \mathrm{~b}$ & $"$ & $170 \mathrm{~b}$ & $"$ \\
\hline
\end{tabular}

\section{Yield of beetroots}

The results from an experiment with four cylindrical beetroots showed that 'Halanga' resulted in the significantly highest total yield followed by 'Unik' and 'Forono' with equal total yields, and 'Rød Valse' with the significantly lowest yield (Table 4). 'Forono' gave almost equal amounts of size 4060 and above $60 \mathrm{~mm}$, which may be applied for processing of two slice sizes of preserved red beet slices. 'Halanga' and 'Unik' resulted in significantly higher yields of beetroots with diameter 40-60 $\mathrm{mm}$ in comparison to the yield of roots with a diameter above $60 \mathrm{~mm}$, and the opposite was obtained for 'Rød Valse', which may be used for processing of most slices in the upper size classes (Table 4). The amount of crooked roots was significantly highest (21\%) for 'Rød Valse' in comparison to $4 \%$ among roots from 'Forono' and 'Halanga' and $7 \%$ from 'Unik', which makes 'Rød Valse' less valuable in comparison to the other three cultivars. 'Forono' had a significantly lower percentage of roots with a diameter below $40 \mathrm{~mm}$ compared to 'Halanga' and 'Unik'. Based on these data it was concluded that 'Forono' may be preferred if the amount of products in the two size classes is equal, and 'Halanga' or 'Unik' may be preferred if the production requires more products with a diameter 40-60 $\mathrm{mm}$ than of the larger slices with a diameter above $60 \mathrm{~mm}$. 
Karl Kaack

Table 4. Yield of four cylindrical beetroots in four size classes (five sortings).

\begin{tabular}{|l|l|l|l|l|l|l|}
\hline Cultivar & Sowing & Harvest & \multicolumn{5}{l|}{ t ha $^{-1}$} \\
\hline & & & $<40 \mathrm{~mm}$ & $40-60 \mathrm{~mm}$ & $>60 \mathrm{~mm}$ & Total \\
\hline 'Forono' & $12^{\text {th }}$ Jun & $1^{\text {st }}$ Oct & $2.2 \mathrm{~b}$ & $37.8 \mathrm{c}$ & $39.0 \mathrm{~b}$ & $79.0 \mathrm{~b}$ \\
\hline 'Halanga' & $"$ & $10^{\text {th }}$ Sep & $5.0 \mathrm{a}$ & $52.7 \mathrm{a}$ & $35.7 \mathrm{c}$ & $93.4 \mathrm{a}$ \\
\hline 'Rød Valse' & $"$ & $1^{\text {st }}$ Oct & $1.4 \mathrm{c}$ & $26.6 \mathrm{~d}$ & $47.8 \mathrm{a}$ & $75.8 \mathrm{c}$ \\
\hline 'Unik' & $"$ & $17^{\text {th }}$ Sep & $2.6 \mathrm{~b}$ & $44.1 \mathrm{~b}$ & $32.3 \mathrm{~d}$ & $79.0 \mathrm{~b}$ \\
\hline 'Forono' & $1^{\text {st }}$ May & 15 th Aug & $1.6 \mathrm{c}$ & $41.6 \mathrm{~b}$ & $9.3 \mathrm{~b}$ & $52.5 \mathrm{~b}$ \\
\hline$"$ & $20^{\text {th }}$ May & 17 th Sep & $5.9 \mathrm{~b}$ & $49.3 \mathrm{a}$ & $13.5 \mathrm{a}$ & $68.7 \mathrm{a}$ \\
\hline$"$ & $17^{\text {th }}$ Jun & $31 \mathrm{st}$ Oct & $7.8 \mathrm{a}$ & $42.5 \mathrm{~b}$ & $3.3 \mathrm{c}$ & $53.6 \mathrm{~b}$ \\
\hline$"$ & $1^{\text {st }}$ Jul & 7 th Nov & $5.6 \mathrm{~b}$ & $28.0 \mathrm{c}$ & $1.2 \mathrm{~d}$ & $34.8 \mathrm{c}$ \\
\hline
\end{tabular}

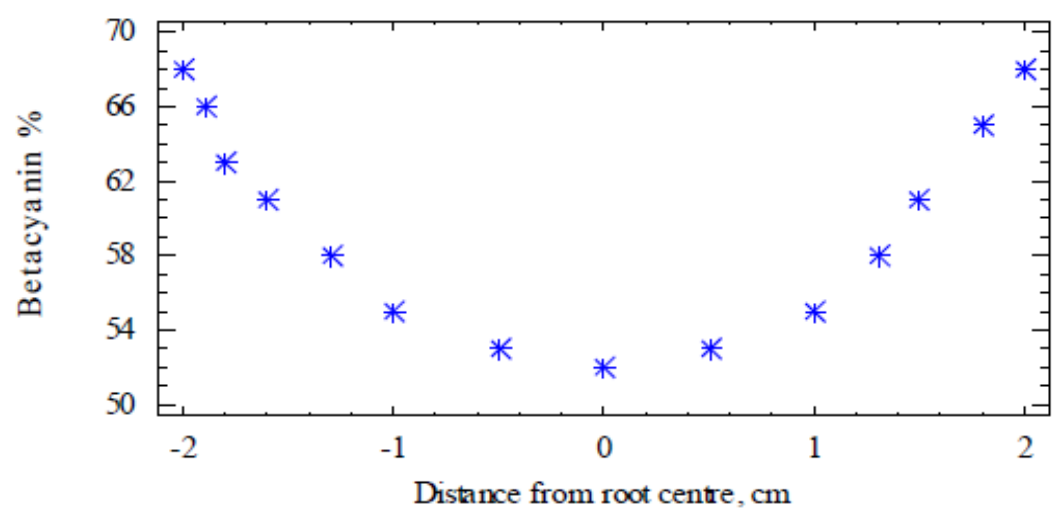

Fig 2. Horizontal concentration of betanin in a beetroot (Rød Valse)

The highest yield of roots in experiment one was obtained by sowing of 'Forono' on the 20 May and harvesting on the 17 September thatalso resulted in the highest yield of beets with a diameter above $60 \mathrm{~mm}$ (Table 4). Sowing $12^{\text {th }}$ June as in experiment two resulted in the highest yield of 'Halanga' and 'Unik' in size 40-60 mm and significantly lower much lower yield of both 'Rød Valse' and 'Forono'.

\section{Chemical compounds}

The red pigments in beet root include betacyanin, iso- $\beta$-cyanate and trace quantities of betacyanine [16] (Table 5) (Drdáket al., 1989) and linear regression analysis of data from experiment 1 showed that the contents of betacyanine in 'Rød Valse'decreased significantly $(\mathrm{P}<0.05)$ with beetroot weight: $\mathrm{mg} / 100 \mathrm{~g}$ betacyanine $=102.8-0.18 *$ weight $(\mathrm{R}=-0.81)$. The vertical concentration of red colorant in beet root surface decreased from $35 \%$ at the leaf basis towards $18 \%$ at medium root height and increased then to $100 \%$ in the root tip and the horizontal distribution increased from $52 \%$ at the root center to $68 \%$ at the root surface (Fig 4). These data shows that the highest concentration of the red betaxanthines occur in the beetroot tip and close to the beetroot peel, which may be taken into consideration peeling in order to reduce the losses of colorants by a too deep peeling. The contents of betacyanin in the three cultivars 'Cylinder', 'Formanova', and 'Rød Valse' were 52.2b, 53.1a and $49.3 \mathrm{cmg} 100 \mathrm{~g}^{-1}$ and the concentration in 'Crosby', 'Detroit' and 'Rubia' were $45.4 \mathrm{~b}, 41,4 \mathrm{c}$ and $48.6 \mathrm{a}$ mg $100 \mathrm{~g}^{-1}$.

The contents of betanin and betaxanthin were highest in 'Forono' and lowest in 'Rød Valse', whereas soluble solids, sucrose and water insoluble dry matter were significantly highest in 'Unik', lowest in 'Rød Valse' and medium in 'Halanga' (Table 5).

Table 5. Chemical composition of beetroots from four cultivars $(n=4)$.

\begin{tabular}{|c|c|c|c|c|c|c|c|c|c|}
\hline \multirow{2}{*}{ Cultivar } & \multirow{2}{*}{$\begin{array}{l}\text { Betanin } \\
\mathrm{mg}_{1} 100 \mathrm{~g}^{-}\end{array}$} & $\begin{array}{l}\text { Vulga- } \\
\text { xanthin }\end{array}$ & \multirow{2}{*}{$\begin{array}{l}\begin{array}{l}\text { Soluble } \\
\text { solids }\end{array} \\
\text { w/w\% }\end{array}$} & Sucrose & Widm & \multirow{2}{*}{\begin{tabular}{|l} 
Nitrate \\
$\mathrm{mg} \mathrm{kg}^{-}$
\end{tabular}} & $\begin{array}{l}\text { Oxalic } \\
\text { acid }\end{array}$ & $\mathrm{Ca}$ & $\mathrm{Mg}$ \\
\hline & & $\begin{array}{ll}\mathrm{mg} & 100 \\
\mathrm{~g}^{-1} & \end{array}$ & & \multicolumn{2}{|c|}{ g $100 \mathrm{~g}^{-1}$} & & \multicolumn{3}{|c|}{$\mathrm{mg} 100 \mathrm{~g}^{-1}$} \\
\hline 'Forono' & $119 \mathrm{a}$ & $96 a$ & $12.7 \mathrm{~b}$ & $9.7 \mathrm{~b}$ & $3.08 \mathrm{~b}$ & $760 \mathrm{~b}$ & $92 a$ & $285 b$ & $170 \mathrm{a}$ \\
\hline 'Halanga' & $82 \mathrm{c}$ & $66 \mathrm{~b}$ & $12.4 \mathrm{~b}$ & $9.5 \mathrm{~b}$ & $3.08 \mathrm{~b}$ & $813 a$ & $79 b$ & $306 a$ & $164 \mathrm{a}$ \\
\hline 'Rød Valse' & $64 d$ & $44 c$ & $11.7 \mathrm{c}$ & $9.3 \mathrm{c}$ & $2.84 \mathrm{c}$ & $685 c$ & $81 \mathrm{~b}$ & $253 c$ & $133 b$ \\
\hline 'Unik' & $97 \mathrm{~b}$ & $65 \mathrm{~b}$ & $13.0 \mathrm{a}$ & $10.4 d$ & $3.23 \mathrm{a}$ & $468 \mathrm{~d}$ & $69 \mathrm{c}$ & $286 c$ & $165 \mathrm{a}$ \\
\hline
\end{tabular}


Soluble solids and sucrose were significantly highest in 'Unik', lowest in 'Rød Valse' and medium in 'Forono' and 'Halanga', whereas water insoluble dry matter was highest in 'Unik', lowest in 'Rød Valse' and medium in 'Forono' and 'Halanga' (Table 5).

Sucrose in beetroots is very important because this sugar contributes considerably to the flavor of the preserved sour sweet beetroot slices and depends on cultivar, sowing, harvest dates, and soil fertility[8].The high concentration of oxalic acid and calcium is not acceptable because it may result in more white precipitate in the jars with preserved red beet slices. A high level of water non-soluble dry matter in 'Unik' and 'Forono' may cause an increasing cooking time. However, this may not be a solid argument to grow 'Rød Valse' with a lower concentration of oxalic acid and a very low concentration of colorants, sucrose and low concentration of magnesia.

Nitrate was significantly highest in 'Halanga' and lowest in 'Unik' while oxalic acid was highest in 'Forono' and lowest in 'Unik'. Oxalic acid was highest in 'Forono' and lowest in 'Unik' and medium in 'Halanga' and 'Rød Valse'. Among the contents of minerals were calcium highest in 'Halanga' followed by 'Forono' and low in both 'Rød Valse' and 'Unik' and magnesium was highest in 'Forono' followed by 'Unik' and 'Halanga' while it was lowest in 'Rød Valse' (Table 6). The variation in calcium and magnesium was rather small.

Table6. Effects of nitrogen fertilization on the chemical composition of beetroots at harvest.

\begin{tabular}{|c|c|c|c|c|c|c|}
\hline $\begin{array}{l}\text { Nitrogen } \\
\mathrm{kg} \mathrm{ha}^{-1}\end{array}$ & 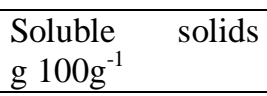 & $\begin{array}{l}\text { Betanin } \\
\mathrm{mg} 100 \mathrm{~g}^{-1}\end{array}$ & 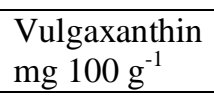 & $\begin{array}{l}\text { Widm }^{1} \\
{\text { g } 100 \mathrm{~g}^{-1}}\end{array}$ & $\begin{array}{l}\text { Nitrate } \\
\mathrm{mg} \mathrm{kg}^{-1}\end{array}$ & $\begin{array}{l}\text { Oxalicacid } \\
{\mathrm{mg} 100 \mathrm{~g}^{-1}}\end{array}$ \\
\hline 40 & $12.3 \mathrm{a}$ & $134 \mathrm{a}$ & $86 \mathrm{c}$ & $3.86 \mathrm{a}$ & $1287 \mathrm{a}$ & $156 \mathrm{c}$ \\
\hline 80 & $12.8 \mathrm{a}$ & $134 \mathrm{a}$ & $93 b$ & $3.72 b$ & $1018 d$ & $180 \mathrm{~b}$ \\
\hline 120 & $12.3 \mathrm{a}$ & $136 a$ & $91 b$ & $3.68 \mathrm{~b}$ & $1255 b$ & $190 \mathrm{a}$ \\
\hline 160 & $12.4 \mathrm{a}$ & $128 \mathrm{a}$ & $98 \mathrm{a}$ & $3.71 \mathrm{~b}$ & $1193 c$ & $188 \mathrm{a}$ \\
\hline
\end{tabular}

Oxalic acid was highest in 'Forono' and lowest in 'Unik' and medium in 'Halanga' and 'Rød Valse'. Among the minerals were calcium highest in 'Halanga' followed by 'Forono' and low in both 'Rød Valse' and 'Unik'.Magnesium was highest in 'Forono' followed by 'Unik' and 'Halanga' while it was lowest in 'Rød Valse' (Table 6). Because the betaxanthin molecules contain nitrogen it was expected that the contents of this yellow colorant would increase by increasing nitrogen fertilization (Table 7). Using from 40 to $160 \mathrm{~kg} \mathrm{~N} \mathrm{ha}^{-1}$ did not affect soluble solids and betanin and the effect on nitrate was unclear, whereas betaxanthin, water insoluble solids and oxalic acid increased significantlyby increasing level of applied nitrogen (Table 7). Application of higher amounts of nitrogen fertilizer up to 258 $\mathrm{kg} \mathrm{N} \mathrm{ha}^{-1}$ resulted in significantly increasing yield of beetroots and contents ofnitrate, glutamin and glutamic acid, whereas betanin, dry matter, and soluble solids decreased significant [15].Decreases in the contentsof soluble solids and colorants occurred by high rates of nitrogen fertilization and low supply of water[3].Glutamin and glutamic acid increased also in the preserved beet slices, which are in accordance with previous research [14]. Betaxanthin increased significant up to $65 \mathrm{~kg} \mathrm{~N} \mathrm{ha}^{-1}$, while glucose and sucrose was unaffected by increased supply of nitrogen to the soil (Table 7).

Table 7. Effect of nitrogen on the concentration of chemical compounds in the cultivar Hunderup $66(n=4)$.

\begin{tabular}{|c|c|c|c|c|c|c|c|c|c|c|c|c|}
\hline & $\begin{array}{l}\text { Rela- } \\
\text { tive } \\
\text { yield }\end{array}$ & $\begin{array}{l}\text { Bet- } \\
\text { anin }\end{array}$ & $\begin{array}{l}\text { Vulg } \\
\text { a- } \\
\text { xan- } \\
\text { thin }\end{array}$ & $\begin{array}{l}\mathrm{Ni}- \\
\text { trate }\end{array}$ & $\begin{array}{c}\text { Dry } \\
\text { mat- } \\
\text { ter }\end{array}$ & $\begin{array}{l}\text { Solu } \\
\text { ble } \\
\text { sol- } \\
\text { ids }\end{array}$ & $\begin{array}{l}\text { Glu- } \\
\text { cose }\end{array}$ & $\begin{array}{l}\mathrm{Su}- \\
\text { crose }\end{array}$ & $\begin{array}{l}\text { Gluta- } \\
\text { mine }\end{array}$ & $\begin{array}{c}\text { Glu- } \\
\text { tamic } \\
\text { acid }\end{array}$ & $\begin{array}{l}\text { Gluta- } \\
\text { mine }\end{array}$ & $\begin{array}{l}\text { Glu- } \\
\text { tamic } \\
\text { acid }\end{array}$ \\
\hline & $\%$ & \multicolumn{3}{|c|}{$\mathrm{mg} 100 \mathrm{~g}^{-1}$} & \multicolumn{8}{|c|}{${\mathrm{g} 100 \mathrm{~g}^{-1}}^{-1}$} \\
\hline & & & & & & & & & \multicolumn{2}{|c|}{ Raw beets } & \multicolumn{2}{|c|}{ Preserved slices } \\
\hline 0 & $52 \mathrm{e}$ & $108 \mathrm{a}$ & $38 b$ & $729 c$ & $\begin{array}{c}16.4 \\
\mathrm{a}\end{array}$ & $14.2 \mathrm{a}$ & $0.20 \mathrm{~b}$ & $11.5 b$ & $0.120 \mathrm{e}$ & $0.026 \mathrm{e}$ & $0.058 \mathrm{e}$ & $\begin{array}{c}0.072 \\
\text { b }\end{array}$ \\
\hline 32 & $68 d$ & $97 b$ & $37 b$ & $610 d$ & $\begin{array}{c}15.8 \\
b\end{array}$ & $13.3 \mathrm{c}$ & $0.25 \mathrm{a}$ & $12.2 \mathrm{a}$ & $0.150 \mathrm{~d}$ & $\begin{array}{c}0.035 \\
d\end{array}$ & $0.093 \mathrm{~d}$ & $\begin{array}{c}0.069 \\
b\end{array}$ \\
\hline 65 & $84 \mathrm{c}$ & $88 \mathrm{c}$ & $45 a$ & 399d & $\begin{array}{c}15.9 \\
b\end{array}$ & $13.8 b$ & $0.19 b$ & $12.3 \mathrm{a}$ & $0.199 \mathrm{c}$ & $0.043 \mathrm{c}$ & $0.131 \mathrm{c}$ & $\begin{array}{c}0.076 \\
b\end{array}$ \\
\hline $\begin{array}{l}12 \\
9\end{array}$ & $89 b$ & $76 d$ & $38 b$ & $\begin{array}{c}1964 \\
b\end{array}$ & $\begin{array}{c}14.5 \\
\mathrm{c}\end{array}$ & $11.7 \mathrm{c}$ & $0.19 b$ & $12.4 \mathrm{a}$ & $0.367 d$ & $\begin{array}{c}0.059 \\
\mathrm{~b}\end{array}$ & $0.158 b$ & $0.089 a$ \\
\hline $\begin{array}{l}25 \\
0\end{array}$ & $100 \mathrm{a}$ & $66 \mathrm{e}$ & $39 b$ & $\begin{array}{c}2185 \\
a\end{array}$ & $\begin{array}{c}13.7 \\
d\end{array}$ & $10.4 \mathrm{~d}$ & $0.20 \mathrm{~b}$ & $9.8 \mathrm{c}$ & $0.505 \mathrm{a}$ & $0.062 \mathrm{a}$ & $0.188 \mathrm{a}$ & $0.084 \mathrm{a}$ \\
\hline
\end{tabular}


It has previously been found that heat treatment of red beet materials may result in degradation of the amino acid glutamine which furthermore may result in formation of pyrrolidone carbonic acid[15, 17, 19] that have a bitter and phenolic off flavor. Sensory evaluation of preserved sour sweet red beet slices by six trained panel members aged 20-40 did not result in finding any off flavor associated to increased application of any of the applied levels of nitrogen (data not shown).

\section{Sowing and harvest}

Data from experiment 2 showed that the contents of betacyaninwas $53.0 \mathrm{c}, 56.4 \mathrm{~b}$ and $60.8 \mathrm{a}$ after sowing $12^{\text {th }}$ May, $6^{\text {th }}$ and $15^{\text {th }}$ Jun and 57.6a, 56.9a and 54.8a mg $100 \mathrm{~g}^{-1}$ after harvest $3^{\text {rd }}$ and $22^{\text {nd }}$ Oct and 12 Nov, which means that the contents of betaxanthins increased significantly by later sowing time, whereas increasing harvest date not affect the contents of betacyaninThe change in betacyanin concentration in 'Forono' with harvest time varied slightly through the harvest period, whereas betaxanthin, soluble solids and water insoluble dry matter increased through the period (Table 8). Betanin increased significant from the first to the second storage day and varied slightly in the remaining part of the storage period, whereas betaxanthin and water non-soluble dry matter seemed to have a maximum after 32 days of storage. Dry matter, soluble solids and extrusion force increased during the growth period, whereas the contents of red pigment decreased [3].

Table 8. Changes in composition of 'Forono'during harvest and cool storage.

\begin{tabular}{|c|c|c|c|c|c|c|c|}
\hline & \multicolumn{5}{|c|}{ Harvest time, days } & & \\
\hline Compound & 1 & 14 & 28 & 42 & 56 & & \\
\hline Betanin, mg $100 \mathrm{~g}^{-1}$ & $105 \mathrm{~b}$ & $106 \mathrm{~b}$ & $90 \mathrm{c}$ & $101 \mathrm{~b}$ & $115 \mathrm{a}$ & & \\
\hline Vulgaxanthin, mg $100 \mathrm{~g}^{-1}$ & $68 \mathrm{e}$ & $78 \mathrm{~d}$ & $83 c$ & $98 \mathrm{~b}$ & $105 \mathrm{a}$ & & \\
\hline Soluble solids, $\%$ & $12.2 \mathrm{e}$ & $11.6 \mathrm{~d}$ & $13.7 \mathrm{c}$ & $13.6 \mathrm{~b}$ & $14.0 \mathrm{a}$ & & \\
\hline Sucrose, g $100 \mathrm{~g}^{-1}$ & $8.8 \mathrm{a}$ & $9.1 \mathrm{bc}$ & $9.7 \mathrm{ab}$ & $9.9 \mathrm{a}$ & $9.3 \mathrm{a}$ & & \\
\hline Oxalic acid, mg $100 \mathrm{~g}^{-1}$ & $105 \mathrm{c}$ & $129 a$ & $121 \mathrm{a}$ & $128 \mathrm{a}$ & $127 \mathrm{a}$ & & \\
\hline \multirow[t]{3}{*}{ Widm, g $100 \mathrm{~g}^{-1}$} & $2.4 \mathrm{~d}$ & $2.8 \mathrm{c}$ & $3.0 \mathrm{~b}$ & $3.2 \mathrm{a}$ & $3.3 \mathrm{a}$ & & \\
\hline & \multicolumn{7}{|c|}{ Storage time, days } \\
\hline & 2 & 29 & 32 & 45 & 56 & 71 & 82 \\
\hline Betanin, mg $100 \mathrm{~g}^{-1}$ & $103 \mathrm{~b}$ & $106 \mathrm{a}$ & $106 \mathrm{a}$ & $107 \mathrm{a}$ & $106 \mathrm{a}$ & $109 \mathrm{a}$ & $107 \mathrm{a}$ \\
\hline Vulgaxanthin, mg $100 \mathrm{~g}^{-1}$ & $86 \mathrm{~d}$ & $89 \mathrm{c}$ & $95 \mathrm{a}$ & $89 \mathrm{c}$ & $87 \mathrm{c}$ & $90 \mathrm{~b}$ & $82 \mathrm{e}$ \\
\hline Soluble solids, \% & $13.0 \mathrm{a}$ & $12.8 \mathrm{a}$ & $13.3 \mathrm{a}$ & $13.5 \mathrm{a}$ & $13.1 \mathrm{a}$ & $13.1 \mathrm{a}$ & $13.2 \mathrm{a}$ \\
\hline Sucrose, g $100 \mathrm{~g}-1$ & $9.7 \mathrm{a}$ & $9.5 \mathrm{a}$ & $9.6 \mathrm{a}$ & $9.5 \mathrm{a}$ & $9.1 \mathrm{~b}$ & $9.0 \mathrm{~b}$ & $8.9 \mathrm{c}$ \\
\hline Oxalic acid, mg $100 \mathrm{~g}^{-1}$ & $121 \mathrm{e}$ & $127 \mathrm{~d}$ & $150 \mathrm{~b}$ & $149 \mathrm{~b}$ & $145 \mathrm{c}$ & $144 \mathrm{c}$ & $158 \mathrm{a}$ \\
\hline Widm, g $100 \mathrm{~g}^{-1}$ & $2.9 \mathrm{~b}$ & $3.2 \mathrm{a}$ & $3.2 \mathrm{a}$ & $3.0 \mathrm{~b}$ & $2.8 \mathrm{~b}$ & $2.9 \mathrm{~b}$ & $3.0 \mathrm{~b}$ \\
\hline
\end{tabular}

Previous research showed that betanin decreased in the last part of the storage period. Water insoluble dry matter increased also from harvest to the first sampling day during storage and decreased during the last part of the storage period as [2]. Oxalic acid in raw beets increased significantly from first to second harvest and remained on this level to the last harvest. During storage oxalic acid increased through the first samplings and remained at this level until the last harvest where a significant increase occurred (Table 8).

In products of preserved slices of beetroot white precipitates appear at the bottom of the jars, which blemish the food and consumers are complaining the qualities because of this defect. A microscopic test showed that the white material contains crystals that were soluble in sulphuric and hydrochloric acid.

The amount of dried white precipitate in up to ten medium size jars with red beet slices varied from 17 to $60 \mathrm{mg}$ in five experimental samples and from 40 to $310 \mathrm{mg}$ in 14 commercial samples (Table 8). And the amount of calcium oxalate varied from 7 to $44 \mathrm{mg}$ corresponding to between 4 and $76 \mathrm{w} / \mathrm{w} \%$ calcium oxalate. The amount of calcium oxalate in the brine varied from 13 to $34 \mathrm{mg} \mathrm{L}^{-1}$ in experimental samples and from 2 to $28 \mathrm{mg} \mathrm{L}^{-1}$ in commercial samples.

The data showed significant relationship between theoretical and analytical contents of calcium oxalate and the level decreased significantly from $\mathrm{pH} 2.0$ to 4.5 . By addition of 0 to $2.0 \mathrm{~g} \mathrm{w} / \mathrm{w} \% \mathrm{NaCl}$ the solubility of calcium oxalate increased from 29 to $66 \mathrm{mg} \mathrm{L}^{-1}$.In raw beetroots soluble sodium and potassium salts and insoluble calcium salts occur [15] and the maximum amount of calcium oxalate was

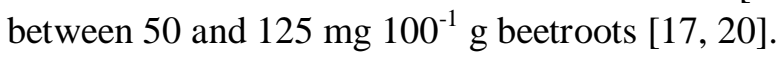


The solubility product of calcium oxalate $\left(\mathrm{CaOxH}_{2} \mathrm{O}\right)$ and the constant dissociation at $25^{\circ} \mathrm{C}$ found in Handbook of Chemistry and Physics [21] and the equilibrium constants ( $\mathrm{j}=$ activity constants) may be written: $\mathrm{K}_{\mathrm{o}}=\left(\mathrm{Ca}^{++}\right)\left(\mathrm{Ox}^{-}\right) \mathrm{j}^{2}=2.57^{-9}(1) ; \mathrm{K}_{1}=(\mathrm{OxH})(\mathrm{H}+) / \mathrm{OxH} 2=5.910^{-2}(2), \mathrm{K}_{2}=\left(\mathrm{Ox}^{--}\right.$ )$\left(\mathrm{H}^{+}\right) /(\mathrm{OxH})=6.410^{-5}$. The amount of solved $\mathrm{Ca}^{++}$may be written $\left(\mathrm{Ca}^{++}\right)+\left(\mathrm{OxH}^{-}\right)+\left(\mathrm{OxH}_{2}\right)$ and the three the three equations $\left(\mathrm{K}_{0}, \mathrm{~K} 1, \mathrm{~K}_{2}\right)$ were used to estimate $\left(\mathrm{Ox}^{--}\right)=\mathrm{K}_{0} /\left(\mathrm{j}\left(1+\mathrm{H}^{+}\right) / \mathrm{K}_{2}+\right.$ $\left(\mathrm{H}^{+}\right)\left(\mathrm{H}^{+}\right) / \mathrm{K}_{1} \mathrm{~K}_{2}$. [22](Daniels and Alberty, 1961). Using these equations, the theoretical solubility of $\mathrm{OxH} 2, \mathrm{Ca}(\mathrm{OxH})_{2}, \mathrm{CaOx}$ and the total amount of dissolved $\mathrm{CaOxH}_{2} \mathrm{O}$ was calculated. On average the red table beets contained $44 \mathrm{mg}$ precipitate $100 \mathrm{~g}^{-1}$ beet slices of which $9 \mathrm{mg}$ were $\mathrm{CaOxH}_{2} \mathrm{O}$.

The effects of sugar $(0 ; 5 ; 10 ; 15: 20 \mathrm{w} / \mathrm{w} \%), \mathrm{NaCl}(0.25 ; 0.5 ; 1.0,15 ; 20 \mathrm{w} / \mathrm{w} \%)$ and acetic acid $(0.0005$; $0.001 ; 0.005 ; 0.01 ; 0.05 ; 0.1 ; 0.5$ mole $^{-1}$ ) on the solubility of calcium oxalate were determined in a fully factorial experiment. The obtained results showed agreements between theoretical and experimental data.

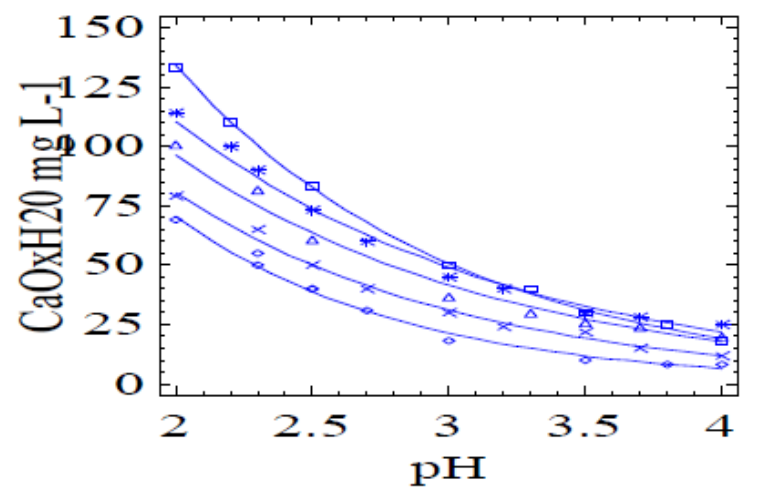

Fig 3. Solubility of calcium oxalate decreased with increased concentration of $\mathrm{NaCl}$.

$\mathrm{NaCl} 0$ squares

$\mathrm{NaCl} 0.25$ stars

$\mathrm{NaCl} 0.5$ triangles

$\mathrm{NaCl} 1$ crosses

$\mathrm{NaCl} 2$ diamonds

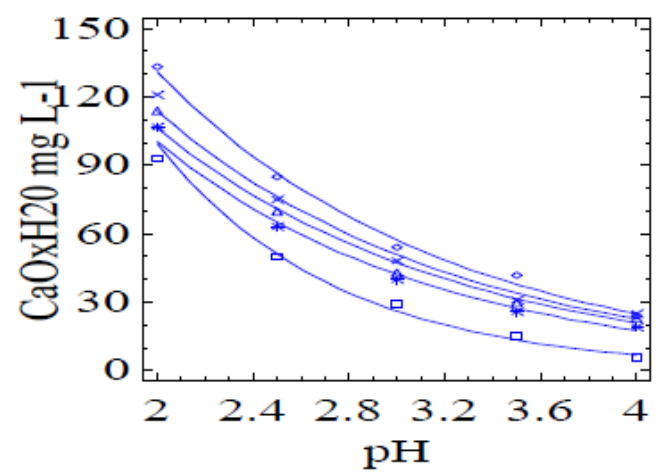

Fig 4 Solubility of calcium oxalate increases with increasing concentration of $\mathrm{NaCl}$ using sugar in the brine.
With sugar
$\mathrm{NaCl} 0$ squares
$\mathrm{NaCl} 0.25$ stars
$\mathrm{NaCl} 0.5$ Triangles
$\mathrm{NaCl} 1$ crosses
$\mathrm{NaCl} 2$ diamonds

In solutions without sucrose decreased the concentration of calcium oxalate significantly with increasing $\mathrm{pH}$ and with increasing level of $\mathrm{NaCl}$ (Fig 3), whereas the concentration of calcium oxalate increased by increasing concentration of $\mathrm{NaCl}$ (Fig. 4). The data fitted with logarithmic functions as for example $\mathrm{CaOxH}_{2} \mathrm{O}=\exp$ (constant a) - (constant $\mathrm{b} * \mathrm{pH}$ ) with correlation coefficients above 0.99. On the basis of these data it may be concluded that the white material in the bottom of jars with red beetroot slices mainly are calcium oxalate and that they occur because of the contents of oxalate in the beetroots and calcium in the tap water. 


\section{DISCUSSION}

The presented data regarding the effects of degree days on beetroot growth between sowing and harvest may be used for coordination of the field production and processing capacities in order to obtain optimum beetroot dimensions and diameter of the processed beetroot slices. The necessary number of sowing and harvest dates may be estimated on the basis of the cultivar, field characteristics and amount of daily slice production. Use of the information about the effects of degree days, and red beet diameter may be used to make plans for sowing and considerations regarding the optimization of harvest time to obtain the maximum number of beet slices and the most efficient exploitation of the processing facilities. Combination of degree days with cultivar, climate conditions and degree days may improve the yield for the farmer. Forecasts and forecasts regarding beetroot size may improve the possibilities for careful planning of harvest and processing capacities taking slice diameter into consideration. The most important quality characteristic is beetroot length because longer beetroots may increase the yield of slices significantly.It may be considered that application of the beetroots with significantly low and high diameter could be used for processing of other beetroot products in order to improve the occurring resources of beetroot materials.

Betacyanin in beetroots cultivars varied from 9 to $135 \mathrm{mg} 100 \mathrm{~g}^{-1}[18,19,22,23]$ The sum of vulgaxantinhin I and II varied from 36-42 and 0.03-0.04 mg $100 \mathrm{~g}^{-1}$. The relationship between betanin (y) and beetroot weight $(\mathrm{x})$ was estimated to be logarithmic: $\mathrm{y}=\mathrm{a}^{*} \mathrm{e}^{\mathrm{bx}}$ or $\log ($ betanin$)=\log \mathrm{a}-\mathrm{bx}$, where $\mathrm{a}$ and $\mathrm{b}$ are constants and that equation shows that the contents of betanin decrease significantly with beetroot size $(\mathrm{P}<0.05)$.

The major color of sour sweet beetroot slices is betacyanin making up to 75-95\% of the total amounts and the remainder red to purple color pigments is isobetacyanin and pre-betacyanin [21]. The concentration of betacyanin in raw beetroots of breeding lines varied from 27 to- $135 \mathrm{mg}$ betacyanin $100 \mathrm{~g}^{-}$ ${ }^{1}[18,19,22]$. The yellow color compounds in red beetroots are betaxanthins that include betaxanthine I and II that encompassed from 36 to $42 \mathrm{mg} 100 \mathrm{~g}^{-1}$ and from 0.03 to $0.04 \mathrm{mg} 100 \mathrm{~g}^{-1}$, respectively $[23,24,25,29]$ Impact of thermal treatment on colour and pigment pattern of red beet [24]and shows thereby the large difference in concentrations found between cultivars [22,23] and the considerable proportion between betacyanines and betaxanthines in red beets [19, 23].Beet colorants are sensitive to heat $[19,22,24,26,27,28,30,32]$ and are degraded according to first order kinetics. Therefore the colorants may be decreased considerably by blanching, cooking and canning [19] (von Elbeet al., 1981). This has been of concern by canning industry [7].

Betacyanines were less stable at $\mathrm{pH} 3$ than 5 and most stable between $\mathrm{pH} 4$ and 5 [25] and betaxanthines were much less stable than betacyanines, whereas betaxanthines are similarly affected by $\mathrm{pH}$ and light as betacyanins [22].

Betacyanines and betaxanthines react with molecular oxygen [25, 30] (von Elbe et al., 1974; [30] and their stability may be improved by antioxidants $[31,33,34]$ or by establishment of a nitrogen atmosphere [30, 31].

The changes in the very important constituent in beetroots including betanin, betaxanthin, soluble solids and water insoluble dry matter depended linearly on time. On average Betacyanin increased

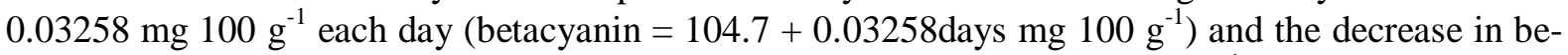

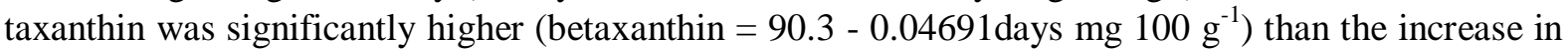
betacyanin. The increase in soluble solids soluble solids (soluble solids $=13.0+0.004307$ days $g 100$ $\mathrm{g}^{-1}$ ) that may be due to respiration and decreases in starches which may be included in the changes of water insoluble soluble solids (Widm $=3.1-0.002039$ days).

Storage of betacyanin solution under low oxygen resulted in decreased pigment degradation because low oxygen levels favor partial recovery of this compound $[11,25]$ The increases in betacyanin and betaxanthin with later sowing/harvesting may be due to less mature beets, which normally have higher contents of these compounds [2, 7]. Total dry matter in Formanova' and 'Rød Valsewere 15.6 and $15.7 \mathrm{w} / \mathrm{w} \%$ while soluble solids were 13.2 and $13.0 \mathrm{w} / \mathrm{w} \%$ and insoluble solids 2.4 and $2.7 \mathrm{w} / \mathrm{w} \%$, respectively. Soluble solids and sucrose in beetroots increased with increasing plant age $[3,18]$. During cool storage at $3.5^{\circ} \mathrm{C}$ reducing sugar decreased significantly (Table 9) as found previously [18]. Firmness of canned beet slices decreased significantly linearly during storage at 18 and $38^{\circ} \mathrm{C}$ [3]. 
Table 9. Yield of four old cylindrical beetroots in four size classes $(n=5)$.

\begin{tabular}{|c|c|c|c|c|c|c|}
\hline Cultivar & Sowing & Harvest & \multicolumn{4}{|c|}{ t ha $^{-1}$} \\
\hline & & & $<40 \mathrm{~mm}$ & $40-60 \mathrm{~mm}$ & $>60 \mathrm{~mm}$ & Total \\
\hline 'Forono' & $12^{\text {th }}$ Jun & $1^{\text {st }}$ Oct & $2.2 \mathrm{~b}$ & $37.8 \mathrm{c}$ & $39.0 \mathrm{~b}$ & $79.0 \mathrm{~b}$ \\
\hline 'Halanga' & $"$ & $10^{\text {th }}$ Sep & $5.0 \mathrm{a}$ & $52.7 \mathrm{a}$ & $35.7 \mathrm{c}$ & $93.4 \mathrm{a}$ \\
\hline 'Rød Valse' & $"$ & $1^{\text {st }}$ Oct & $1.4 \mathrm{c}$ & $26.6 \mathrm{~d}$ & $47.8 \mathrm{a}$ & $75.8 \mathrm{c}$ \\
\hline 'Unik' & $"$ & $17^{\text {th }}$ Sep & $2.6 \mathrm{~b}$ & $44.1 \mathrm{~b}$ & $32.3 \mathrm{~d}$ & $79.0 \mathrm{~b}$ \\
\hline 'Forono' & $1^{\text {st }}$ May & 15 th Aug & $1.6 \mathrm{c}$ & $41.6 \mathrm{~b}$ & $9.3 \mathrm{~b}$ & $52.5 \mathrm{~b}$ \\
\hline$"$ & $20^{\text {th }}$ May & 17 th Sep & $5.9 \mathrm{~b}$ & $49.3 \mathrm{a}$ & $13.5 \mathrm{a}$ & $68.7 \mathrm{a}$ \\
\hline$"$ & $17^{\text {th }}$ Jun & 31 st Oct & $7.8 \mathrm{a}$ & $42.5 \mathrm{~b}$ & $3.3 \mathrm{c}$ & $53.6 \mathrm{~b}$ \\
\hline$"$ & $1^{\text {st } J u l}$ & 7 th Nov & $5.6 \mathrm{~b}$ & $28.0 \mathrm{c}$ & $1.2 \mathrm{~d}$ & $34.8 \mathrm{c}$ \\
\hline
\end{tabular}

Calcium and magnesium may to some degree be associated with water insoluble solids. Even trace amounts of mineral cations such as iron, cupper, tin and aluminum accelerate betacyanin degradation during processing $[24,32,33]$.The solubility of calcium oxalate decreases by increasing $\mathrm{pH}$ from 2 to 4 both with and without sugar in the brine. Without sugar decreased the solubility of calcium oxalate with increasing contents of $\mathrm{NaCl}$ whereas increasing levels of $\mathrm{NaCl}$ caused increasing solubility of calcium oxalate by presence of sugar in the brine. These effects of increasing concentration of salts are mainly due to increased ion activity constants [21]. Data from small experiments showed that occurrence of the white material may be avoided by using $1 \mathrm{w} / \mathrm{w} \% \mathrm{NaCl}$ and $\mathrm{pH} 3.6$ or by increases in acetic acid, phosphoric acid or citric acid in comparison with or without using $\mathrm{NaCl}$.

\section{REFERENCES}

[1] Kaack, K., 1972. Taste evaluation of fruits and vegetables (Danish J. Plant and Soil Sci. 76, 604610.

[2] Kaack K., 1977. Changes in contents of colorant substances in red beet during growth, storage, industrial processing of red canned beets. Danish J. Plant and Soil Sci. 81, 165-170. (1977).

[3] Delgado-Vargas, F., Jiménez A.R., Paredes-López O., Natural pigments: Carotenoids, anthocyanins, and Betalains -characteristics, biosynthesis, processing and stability. Crit. Rev. Food Sci. Nutr. 40, 173-289.(2000).

[4] Rao, M.A., Kenny, L.F., Shannon, S., Bourne, M.C. 1977. Firmness and thermal conductivity of red beets in storage. J. Food Process Engineering 1, 259-267.

[5] Shallenberger, R.S., Moyer, J.C., Relationship between pyrrolidone carboxylic acid and an offflavor in beet puree. J. Agric. Food Chem. 6, 604-606. (1958).

[6] Markakis, P., Amon, A., The presence and origin of 2-pyrrolidonecarboxylic acid in processed grape juice and its concentrate. Food Technol. 23, 1463-1465. (1961).

[7] Lusas, E.W., Rice, A.C., Weckel, K.G., Changes in the color of canning beets. : I. Changes during growth and processing: 2. Effects of variables in processing on the color of canned beets. 3 . Effects of additives on color of canned beets. Res. Bull. 218, 1-23. University of Wisconsin Madison. (1960).

[8] Shannon, S., Changes in soluble solids, red pigment content, and firmness of table beet cultivars with growing time and season. J. Amer. Soc. Hort. Sci. 97, 223-228. (1972).

[9] Kaack, K. Effects of sowing date, harvest time, and storage on raw beet quality and processing requirements. Danish J.Plant and Soil Sci 92, 316-324. (1988a).

[10] Kaack K. Quality assessments of cylindrical red beet (Beta vulgaris L.) cultivars for programmed growing. Danish J. Plant and Soil Sci 92, 325-327. (1998b).

[11] Nilsson, T., Studies into pigments in beetroot. Lantbrukshögskolans Annaler, 36, 179-210. (1970).

[12] Überla, A. K., Faktorenanalyse. Springer, Berlin. (1971).

[13] Sharma S. Applied Multivariate Techniques (1996).

[14] Herrbach, K.M., Stintzing, F.C. Carle R Impact of thermal treatment on color and pigment pattern of red Beet (Beta vulgaris L.). J Food Sci 69, C491-C498 (2004).

[15] Ugrinovic, K. Effect of nitrogen fertilization on quality and yield of red beet (Beta vulgaris L.). Acta Hortic.506, 99-104. (1999). 
[16] Drdák, M., Vallová, M., Daučik, P., Greif, G., Effect of fermentation on the composition of the red beet pigments. Z. Lebensm. Unters. Forsch. 188, 547-550. (1989).

[17] Mahdi, A.A., Rice A.C., Weckel, K.G., Effect of pyrrolidonecarboxylic acid on flavor of processed fruits and vegetables. J. Agric. Food Chem.9, 143-146. (1961).

[18] Davies A.C.W., Oswin, P., Rutherford, P.O., Tucker, W.G., Phelps, K., Investigations on the long term storage of red beet. Expl. Hort. 28, 15-30. (1976).

[19] Luh, B.S., Antonakos, J., Daoud, H.N., Chemical and quality changes in strained carrots canned by a septic and retort processing. Food Technol. 23, 377-381. (1969).

[20] Adrianse A. and RobbersJ. E., Über eine modifizierte Gesamtoxalatbestimmung in Gemüsen. Z. Le-bensm. Unters. Forsch. 141, 158-60.(1969).

[21] Daniels, F., Alberty, R.A., Physical Chemistry 2nd edition. John Wiley and Sons Inc. New York. (1961).

[22] Sapers, G. M., Hornstein J. S., Varietal differences in colorant properties and stability of red beet pigments. Food Sci. 44, 1245-1248. (1979).

[23] Gasztonyi, M.N., Daood, H., Hájos, M.T., Biacs, P., Comparison of red beet (Beta vulgaris var conditiva) varieties on the basis of their pigment components. J. Sci. Food Agric. 81, 932-933. (2001). and retort processing. Food Technol. 23, 377-381. (1969).

[24] Pasch J.H., von ElbeJ.H., Betanine stability in buffered solutions containing organic acids, metal cations, antioxidants, or sequestrants. J. Food Sci. 44, 72-74\& 81.(1979).

[25] Kujala, T.S., Loponen, J.M., Klika, K.D., Pihjala, K. J., Phenolics and betacyanin in beetroot (Beta vulgaris L.). Distribution and effect of cold storage on the content of total phenolics and three individual compounds. J. Agric. Food Chem. 48, 5338-5342. (2000).

[26] Saguy J., Kopelman J. F., Mizrahi., S., Computer-aided determination of beet pigments J. Food Sci. 43,124-127. (1978).

[27] Saguy, J., Thermostability of red beet pigments (Betanine and Vulgaxanthin-I). Influence of pH and temperature. J. Food Sci. 44, 1554-1555. (1979).

[28] Savolainen, K., Kuusi, T., The stability properties of golden beet and red beet pigments. Influence of $\mathrm{pH}$ temperature and some stabilizers. Z. Lebensm. Forsch. 166, 19-22.(1978).

[29] Singer, J.W., von Elbe J.W., Degradation rate of vulgaxanthine I. J. Food Sci.45, 489491.(1980).

[30] von Elbe, J.H., Sy, S.H.,Maing, I.Y., Abelman,W.H.,Quantitative analysis of betacyanins in red table beets (Beta vulgaris).J. Food Sci.37, 932-934. (1972).

[31] von Elbe, J.H., Schwartz,S.J., Hildenbrand, B.E.,Loss and generation of betacyanin pigments during processing of red beets. J. Food Sci.46, 1713-1715.(1981).

[32] Wyler, H., Vincenti, G., Mercier, M., Saguy, G., Dreiding,A. S. Zur Konstitution des Randenfarbstoffes Betanin. Helv. Chim. Acta 42, 1696-1698.(1959).

[33] Czapski, J., Heat stability of betacyanins in red beet juice and in betanin solutions. Z. Lebensm. Untes-Forsch. 191, 275-278. (1990).

[34] Huang, A.S., von Elbe J. H., Kinetics of the degradation and regeneration of betanine. J. Food Sci. 50, 1115-1120\&1129. (1985).

[35] Huang, A.S. and von Elbe, J. H., Effect of $\mathrm{pH}$ on the degradation and regeneration of betanine. J. Food Sci.52, 1689-1693. (1987).

[36] E., L., and von Elbe J. H., Degradation kinetics of betanine in solutions as influenced by oxygen. J. Agric. Food Chem. 30, 708-712. (1982).

[37] Attoe E.L., von Elbe, J. H., Oxygen Involvement in betanine degradation: effect of antioxidants. J. Food Sci. 50, 106-110. (1985).

[38] Han, D.; SJ Kim; S.H. Kim, Kim, DM., Repeated regeneration of degraded red beet juice pigments in the Presence of antioxidants J. Food Sci 63,69-72.

[39] Attoe EL, Von Elbe JH (1984) Oxygen involvement in betanin degradation. Oxygen uptake and influence of metal ions. Z Lebensm-Unters Forsch 179: 232-236.

[40] Snell, A.D. and Snell, C.T. 1949. Colometric Methods of Analysis. D. van Nostrand, New York. 